\title{
Risk factors for metastatic uveal melanoma after trans-scleral local resection
}

\author{
Bertil E Damato, James Paul, Wallace S Foulds
}

\begin{abstract}
Aims-This study reports the metastatic death rate after trans-scleral local resection of uveal melanoma and identifies relevant risk factors.

Methods-Local resection was performed in 332 patients (mean age 51 years), with follow up ranging to 20.9 years (median for living patients 33 months). The tumours had a mean largest basal diameter of 13.1 $\mathrm{mm}$ and mean thickness of $7.5 \mathrm{~mm}$, with 135 containing epithelioid cells. Risk factors were identified by Cox analysis and metastatic rates demonstrated using Kaplan-Meier curves.

Results-There were 52 deaths from metastatic melanoma. The significant risk factors were (i) age more than 60 years at treatment $(p=0.001)$, (ii) mixed/epithelioid tumours $(p=0 \cdot 003)$, (iii) superior location of mixed/epithelioid tumours (over and above (ii)) $(p=0.001)$, (iv) largest basal tumour diameter of 16 mm or more $(p<0.001)$, (v) lack of adjunctive radiotherapy $(p=0.031)$, (vi) secondary enucleation for bulky residual recurrent tumour $(p=0.002)$, and (vii) secondary enucleation for small residual/ recurrent tumour extraocularly $(p=0 \cdot 019)$. Metastatic death was not significantly associated with (i) incomplete tumour excision $(p=0.163)$, and (ii) small residual/recurrent tumour treated by enucleation $(p=0.855)$.

Conclusions-Survival diminished from $\mathbf{9 2} \%$ at 15 years if less than two risk factors were present to less than $30 \%$ in 3.5 years if more than three risk factors were present.
\end{abstract}

(Br f Ophthalmol 1996; 80: 109-116)

Uveal melanoma is the commonest primary malignancy in the eye. Despite successful eradication of the primary tumour, about $50 \%$ of all patients ultimately develop metastatic disease, ${ }^{1}$ which is invariably fatal. ${ }^{2}$ Factors reported to be associated with an increased risk of metastatic disease include tumour size, ${ }^{3}$ number of epithelioid cells per high power field, ${ }^{4}$ nucleolar size, ${ }^{5}$ hyperploidy, ${ }^{6}$ lymphocytic infiltration, ${ }^{7}$ tumour pigmentation, ${ }^{8-10}$ presence of closed microvascular loops, ${ }^{11}$ acoustic tissue characteristics, ${ }^{12}$ extrascleral tumour extension, 81013 ciliary body involvement, ${ }^{14}$ old age at diagnosis, ${ }^{9}$ rapid tumour regression after radiotherapy, ${ }^{15} 16$ and others.

In specialist centres, enucleation is avoided whenever possible in favour of less mutilating forms of treatment, which are aimed at conserving vision and the eye and which include brachytherapy, ${ }^{17-19}$ teletherapy, ${ }^{20} 21$ and trans-scleral local resection. ${ }^{22-25}$ Previous studies suggest that survival after enucleation is not significantly better than after radiotherapy ${ }^{26}$ or local resection. ${ }^{27}$ Sight conserving treatment has been encouraged by a widely shared belief that treatment does not influence survival in patients with medium sized and large tumours because fatal tumour dissemination has already occurred by the time the patient first presents. ${ }^{28} 29$

The aims of this study were to (i) identify predictive risk factors for metastasis after transscleral local resection, and (ii) establish whether the prognosis for survival is affected by incomplete tumour resection and by adjunctive plaque radiotherapy.

\section{Patients, materials, and methods}

PREOPERATIVE ASSESSMENT

Our methods of preoperative assessment are described elsewhere. ${ }^{25} 30$ The following data were obtained at the time of treatment or subsequently by reviewing photographs and records: (i) patient age and sex; (ii) Snellen visual acuity measured with spectacles, pinhole, or unaided, as clinically indicated; (iii) tumour height and largest and smallest basal tumour diameters as measured by B-scan ultrasonography; (iv) location of anterior and posterior margins of the tumour; and (v) coronal and sagittal location of the tumour. The tumour was said to have 'posterior tumour extension' if its posterior margin was situated at or within 1 disc diameter of the disc margin or fovea. The coronal location of the tumour was categorised as 'vertical' if the 'centre of gravity' of the tumour was located on a vertical line passing through the fovea, and 'nasal' or 'temporal' if the tumour was placed medical or lateral to the fovea.

\section{SURGICAL TECHNIQUE}

The surgical techniques are described in detail elsewhere. ${ }^{25}$ Briefly, a rectangular lamellar scleral flap, was dissected over the tumour, after defining the tumour margins by transpupillary transillumination. The deep sclera and choroid were divided some $3-5 \mathrm{~mm}$ from the tumour, which was removed avoiding retinal damage whenever possible. Since 1986, partial ocular decompression was routinely performed, either before the dissection of the scleral flap by three port vitrectomy (WSF), or after preparation of the flap via a single sclerotomy and without infusion (BED). 
Haemorrhage was minimised by lowering the systolic blood pressure to approximately 40-60 $\mathrm{mm} \mathrm{Hg.}{ }^{31}$ The sclera was closed with interrupted 8-0 virgin silk, nylon, or vicryl sutures. Any small extraocular tumour nodule was excised with a surround of full thickness sclera and the defect in the lamellar flap was closed with a lamellar graft taken from a healthy part of the same eye. Adjunctive plaque radiotherapy was applied routinely and indiscriminately (that is, as often as possible) between the years of 1986 and 1989, but before and after this period such radiotherapy was administered only if there was definite or probable residual tumour. A ruthenium plaque was used, except in five cases treated before 1981, when only a cobalt plaque was available. External plombage and/or internal tamponade with gas or silicone were used to prevent retinal detachment if a large retinal defect was created.

\section{PATHOLOGICAL EXAMINATION}

Tumours were categorised as spindle cell, mixed, or epithelioid but the latter two types were considered together for this study because of the small number of purely epithelioid tumours. Surgical clearance was considered adequate if normal choroid was present beyond the tumour margin, uncertain if tumour extended close to the excision edge, and inadequate if tumour was present at the resection edge. Residual and recurrent tumours in enucleated eyes were categorised as 'large' if they measured approximately $10 \mathrm{~mm}^{3}$ or greater.

\section{PATIENT FOLLOW UP}

After the local resection, patients were reviewed after 1 month, 6 months, and then annually, if possible, unless more frequent visits were indicated because of complications. The following data were recorded: (i) visual acuity, measured with a Snellen chart either unaided, or with current spectacles, or pinhole as appropriate; and (ii) ocular and systemic complications together with the date of their diagnosis. Persistent intraocular tumour after local resection was categorised as (i) 'residual tumour' if present from the time of the operation (that is, diagnosed within the first 40 postoperative days), or (ii) 'recurrent tumour' if the tumour regrew from invisible microscopic deposits after apparently complete resection. Residual tumour and recurrent tumour were categorised as 'possible' when pigmentation could not be differentiated from retinal pigment epithelial hyperplasia and 'definite' when the diagnosis was certain. During most of the study, postoperative laser photocoagulation was applied only to 'possible' or 'definite' residual and recurrent tumours, whereas in the latter part of the study a double row of confluent photocoagulation burns was routinely applied to margins of the coloboma in all patients irrespective of whether or not residual tumour was suspected.

\section{STATISTICAL METHODS}

During the 18 months preceding the close of the study or the date of death, follow up data were obtained on $93 \%$ of all the 272 live patients, with all patients lost to follow up living overseas. The data were derived from examinations performed by one of the clinical authors (BED or WSF) or by the referring ophthalmologists, who returned questionnaires.

Information about the cause of death was obtained from family practitioners, referring ophthalmologists, and cancer registries. If a post mortem was not performed, the cause of death was assumed to be metastatic melanoma unless an alternative diagnosis had been confirmed. Follow up for patients still alive at the close of the study varied from 7 days to 20.9 years, with a median of 33 months. Ninety six patients were followed up for more than 5 years and 24 of these were followed up for more than 10 years.

In relation to metastatic death, $\mathrm{p}$ values for the univariate comparisons of time to death between different groups were derived by fitting Cox's proportional hazards model $^{32}$ to the data. Estimates of relative event rates were obtained in the same way. A forward stepwise procedure ( $p$ to enter $=p$ to remove $=0.05$ ) was used in conjunction with Cox's proportional hazards model to identify those factors influencing metastatic death most profoundly. A backward stepwise procedure was also used and gave the same model as the forward procedure and is therefore not referred to specifically in the results section. As with the outcome of any statistical analysis, the findings presented should be interpreted critically taking into account both the statistical and the clinical levels of significance. Such caution is all the more necessary with stepwise procedures as they produce exaggerated $p$ values. In the analysis of the effect of various postoperative events on the risk of metastatic death, Cox's proportional hazards model was again used together with techniques for modelling the effect of time dependent covariates. ${ }^{32}$ Such techniques allow the influence of postoperative events to be estimated properly by including them only after the time that they occur for each patient. In these models the pretreatment and treatment variables already shown to be of prognostic importance were also included. Kaplan-Meier estimates ${ }^{33}$ were used to draw survival curves. These curves were terminated when there were fewer than five patients at risk.

Patients were included in the study if they had primary choroidectomy, cyclochoroidectomy (with or without iridectomy) or iridocyclectomy. They were excluded from the study if the operation was abandoned in favour of another form of conservative therapy or enucleation.

For the statistical analysis, persistent tumour in enucleated eyes was categorised as showing extraocular extension only if the extraocular extension was diagnosed at the same time as the recurrent tumour. 
Table 1 Metastatic death after local resection. Univariate analysis

\begin{tabular}{|c|c|c|c|c|c|c|}
\hline \multirow[b]{2}{*}{ Variable } & \multirow[b]{2}{*}{ Categories } & \multirow[b]{2}{*}{$\begin{array}{l}\text { No of } \\
\text { patients }\end{array}$} & \multirow[b]{2}{*}{$\begin{array}{l}\text { Relative rate of } \\
\text { metastatic death }\end{array}$} & \multicolumn{2}{|c|}{$95 \%$ Confidence interval for $R R$} & \multirow[b]{2}{*}{$p$ Value } \\
\hline & & & & $\begin{array}{l}\text { Lower } \\
\text { limit }\end{array}$ & $\begin{array}{l}\text { Upper } \\
\text { limit }\end{array}$ & \\
\hline Sex & Female & 163 & $1 \cdot 00$ & - & - & 0.541 \\
\hline \multirow[t]{2}{*}{ Age at diagnosis (years) } & $\begin{array}{l}\text { Male } \\
<40 \\
40-60\end{array}$ & $\begin{array}{r}169 \\
70\end{array}$ & $\begin{array}{l}1.19 \\
1.00 \\
1.10\end{array}$ & $\begin{array}{l}0.69 \\
-0.48\end{array}$ & $\begin{array}{l}2.05 \\
- \\
3.00\end{array}$ & $<0.001$ \\
\hline & $\begin{array}{l}40-60 \\
>\end{array}$ & $\begin{array}{r}172 \\
90\end{array}$ & $\begin{array}{l}1 \cdot 19 \\
4 \cdot 86\end{array}$ & $\begin{array}{l}0.48 \\
1.99\end{array}$ & $\begin{array}{r}3.00 \\
11.87\end{array}$ & \\
\hline \multirow{2}{*}{ Eye } & Right & 146 & 1.00 & - & - & 0.232 \\
\hline & Left & 186 & 0.72 & 0.42 & $1 \cdot 24$ & \\
\hline \multirow[t]{2}{*}{ Initial vision } & $\begin{array}{l}6 / 6-6 / 12 \\
6 / 18-6 / 36\end{array}$ & $\begin{array}{r}192 \\
81\end{array}$ & $\begin{array}{l}1 \cdot 00 \\
1.08\end{array}$ & $\overline{0.55}$ & $\overline{0.13}$ & 0.967 \\
\hline & $6 / 60$ or worse & 59 & $\begin{array}{l}1.06 \\
1.06\end{array}$ & $\begin{array}{l}.35 \\
0.53\end{array}$ & $2 \cdot 13$ & \\
\hline \multirow{2}{*}{$\begin{array}{l}\text { Anterior tumour margin } \\
\text { (in relation to ora serrata) }\end{array}$} & Posterior & 166 & $1 \cdot 00$ & - & - & 0.091 \\
\hline & Anterior & 166 & 1.63 & 0.92 & $2 \cdot 90$ & \\
\hline \multirow{2}{*}{$\begin{array}{l}\text { Posterior tumour margin } \\
\text { (in relation to disc or fovea) }\end{array}$} & $\geqslant 1 \mathrm{DD}$ & 290 & 1.00 & - & - & 0.391 \\
\hline & $<1 \mathrm{DD}$ & 42 & 0.64 & $0 \cdot 23$ & $1 \cdot 78$ & \\
\hline \multirow[t]{2}{*}{ Coronal tumour position } & Nasal to fovea & 136 & $1 \cdot 00$ & - & & 0.063 \\
\hline & Vertical midline & 39 & $2 \cdot 64$ & $1 \cdot 14$ & $6 \cdot 12$ & \\
\hline \multirow{3}{*}{ Sagittal tumour position } & $\begin{array}{l}\text { Temporal to fovea } \\
\text { Superior to fovea }\end{array}$ & 157 & 1.61 & 0.85 & $3 \cdot 06$ & 0.324 \\
\hline & Horizontal meridian & 67 & 0.97 & 0.47 & $2 \cdot 00$ & 0.324 \\
\hline & Inferior to fovea & 146 & 0.65 & 0.35 & $1 \cdot 20$ & \\
\hline \multirow[t]{3}{*}{ Operation type } & Iridocyclectomy & 37 & 1.00 & - & & 0.033 \\
\hline & Choroidectomy & 206 & 2.57 & 0.77 & 8.55 & \\
\hline & Cyclochoroid & 89 & 4.03 & 1.21 & $13 \cdot 50$ & \\
\hline \multirow[t]{2}{*}{ Adjunctive brachytherapy } & No & 282 & 1.00 & - & -100 & $0 \cdot 111$ \\
\hline & Yes & $\begin{array}{r}50 \\
165\end{array}$ & 0.40 & $0 \cdot 12$ & $1 \cdot 29$ & \\
\hline Ocular decompression & No & 165 & 1.07 & $\overline{0} \cdot 5$ & $-\overline{2} \cdot 13$ & 0.828 \\
\hline \multirow{3}{*}{$\begin{array}{l}\text { Surgical clearance (on } \\
\text { histology) }\end{array}$} & $\begin{array}{l}\text { Yes } \\
\text { Yes }\end{array}$ & 167 & 1.00 & - & $2 \cdot 13$ & $0 \cdot 163$ \\
\hline & $\begin{array}{l}\text { Yes } \\
\text { Uncertain }\end{array}$ & $\begin{array}{r}125 \\
43\end{array}$ & $\begin{array}{l}1.00 \\
0.27\end{array}$ & 0.06 & $1 \cdot 15$ & 0.163 \\
\hline & & 164 & 0.94 & 0.53 & 1.65 & \\
\hline \multirow{2}{*}{$\begin{array}{l}\text { Tumour thickness (mm) } \\
\text { (pathology measurement) }\end{array}$} & $<5$ & & 1.00 & - & & 0.058 \\
\hline & $5-8$ & 152 & 1.73 & 0.59 & $5 \cdot 05$ & \\
\hline \multirow{2}{*}{$\begin{array}{l}\text { Tumour diameter }(\mathrm{mm}) \\
\text { (pathology measurement) }\end{array}$} & $\begin{array}{r}>8 \\
<11\end{array}$ & $\begin{array}{r}108 \\
71\end{array}$ & $\begin{array}{l}2.91 \\
1.00\end{array}$ & $1 \cdot 00$ & $8 \cdot 41$ & $<0.001$ \\
\hline & $11-15$ & 179 & 2.93 & $1 \cdot 02$ & 8.43 & \\
\hline \multirow{2}{*}{ Cell type } & $>15$ & $\begin{array}{r}72 \\
107\end{array}$ & $7 \cdot 40$ & $2 \cdot 54$ & $21 \cdot 58$ & \\
\hline & $\begin{array}{l}\text { Spindle } \\
\text { Mixed/epithelioid }\end{array}$ & $\begin{array}{l}197 \\
135\end{array}$ & $\begin{array}{l}1.00 \\
5 \cdot 91\end{array}$ & $\overline{3} \cdot 13$ & $\overline{11} \cdot 15$ & $<0.001$ \\
\hline
\end{tabular}

*Pathological height not recorded for 20 patients; tpathological diameter not recorded for 10 patients.

\section{Results}

SAMPLE

The study included 332 patients (169 male, 163 female; mean age 51 years) (Table 1 ). The tumours had a mean largest tumour diameter (LTD) of $13 \cdot 1$ (SD $4 \cdot 1$ ) $\mathrm{mm}$ and a mean thickness of 7.5 (SD 3.0 ) $\mathrm{mm}$, as measured by the pathologist. The tumours extended anterior to the ora serrata in 166 cases and to within 1 disc diameter (DD) of the optic disc margin or fovea in 42 cases. Epithelioid cells were noted in 135 tumours. A total of 50 patients received adjunctive plaque radiotherapy at the time of the local resection. As reported more fully in a parallel study, residual tumour diagnosed immediately after the local resection occurred in 24 eyes and delayed tumour recurrence from microscopic deposits occurred in another 56 eyes. ${ }^{34}$ Thirty three eyes were enucleated because of residual tumour, which was categorised as 'large' in nine cases (with or without extraocular extension), and 'small' in 24 patients, nine of whom were classified as having extraocular tumour extension. Fifty two patients died of metastatic disease and another eight patients died of other causes, which included carcinoma of the bronchus (two), pneumonia (two), myocardial infarction (two), suicide (one), and gastroenteritis (one).

PREDICTIVE FACTORS

Univariate analysis showed that the variables predicting metastatic death were (i) age greater than 60 years at the time of diagnosis $(p<0.001)$, (ii) presence of epithelioid cells $(\mathrm{p}<0.001)$, (iii) largest tumour diameter of 16 mm or more $(p<0.001)$, (iv) choroidectomy and cyclochoroidectomy types of local resection $(p=0.033)$ (Table 1). A forward stepwise Cox regression indicated in a multivariate setting that the statistically significant predictors

Table 2 Metastatic death after local resection. Multivariate analysis

\begin{tabular}{|c|c|c|c|c|c|c|}
\hline \multirow[b]{2}{*}{ Variable } & \multirow[b]{2}{*}{ Categories } & \multirow[b]{2}{*}{$\begin{array}{l}\text { No of } \\
\text { patients }\end{array}$} & \multirow[b]{2}{*}{$\begin{array}{l}\text { Relative rate of } \\
\text { metastatic death }\end{array}$} & \multicolumn{2}{|c|}{$95 \%$ Confidence interval for $R R$} & \multirow[b]{2}{*}{ p Value } \\
\hline & & & & $\begin{array}{l}\text { Lower } \\
\text { limit }\end{array}$ & $\begin{array}{l}\text { Upper } \\
\text { limit }\end{array}$ & \\
\hline Age at diagnosis (years) & $\begin{array}{l}\leqslant 60 \\
>60\end{array}$ & $\begin{array}{r}235 \\
87\end{array}$ & $\begin{array}{l}1 \cdot 00 \\
3 \cdot 14\end{array}$ & $\overline{1} \cdot 75$ & $\overline{5} \cdot 62$ & $<0.001$ \\
\hline \multirow{2}{*}{$\begin{array}{l}\text { Sagittal tumour position } \\
\text { (with respect to fovea) } \\
\text { Adjunctive brachytherapy }\end{array}$} & Superior/horizontal & 181 & 1.00 & -9 & -4 & 0.004 \\
\hline & $\begin{array}{l}\text { Inferior } \\
\text { No }\end{array}$ & $\begin{array}{l}141 \\
274\end{array}$ & $\begin{array}{l}0.40 \\
1.00\end{array}$ & $0 \cdot 22$ & $0 \cdot 75$ & 0.029 \\
\hline \multirow{4}{*}{$\begin{array}{l}\text { Tumour diameter (mm) } \\
\text { (pathology measurement) } \\
\text { Cell type }\end{array}$} & $\begin{array}{l}\text { Yes } \\
<16\end{array}$ & $\begin{array}{r}48 \\
250\end{array}$ & $\begin{array}{l}0.26 \\
1.00\end{array}$ & $\begin{array}{l}0.08 \\
-\end{array}$ & $0 \cdot 87$ & \multirow{4}{*}{$\begin{array}{r}0.001 \\
<0.001\end{array}$} \\
\hline & $\geqslant 16$ & 72 & $2 \cdot 87$ & $1 \cdot 58$ & $\overline{5} \cdot 22$ & \\
\hline & Spindle & 191 & $1 \cdot 00$ & - & - & \\
\hline & Mixed/epithelioid & 131 & $5 \cdot 48$ & $2 \cdot 76$ & $10 \cdot 90$ & \\
\hline
\end{tabular}

*Total number of patients is adjusted to 322 because pathological diameter is not recorded for 10 patients. 


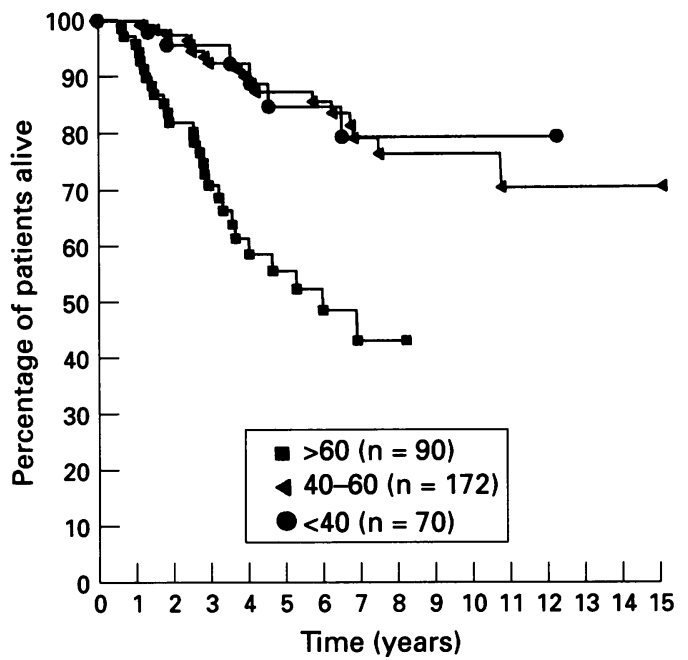

Figure 1 Kaplan-Meier curves showing the percentage of live patients according to age at the time of treatment. Patients older than 60 years showed were more likely to die of metastatic disease than younger patients.

for metastatic death were (i) patient age more than 60 years at diagnosis $(p<0.001)$, (ii) presence of epithelioid tumour cells $(p<0.001)$, (iii) largest tumour diameter of 16 $\mathrm{mm}$ or more $(\mathrm{p}=0.001)$, (iv) superior tumour location within the eye $(p=0.004)$, and (v) lack of adjunctive plaque radiotherapy $(\mathrm{p}=0.029)$ (Table 2). Adjunctive plaque radiotherapy tended to be applied to large tumours having a poorer prognosis; $25 \%$ of patients with a largest tumour diameter greater than $15 \mathrm{~mm}$ received adjunctive plaque radiotherapy compared with $15 \%$ of those with $11-15 \mathrm{~mm}$ tumours and $6 \%$ of those less than $11 \mathrm{~mm}$ in diameter. Because the multivariate analysis took account of the effect of tumour size, the advantage of plaque radiotherapy therefore became apparent statistically at this stage of the analysis. Figures 1-4 show the Kaplan-Meier survival curves giving an indication of time to metastatic death according to age, presence of epithelioid cells, largest tumour diameter, and adjunctive plaque radiotherapy.

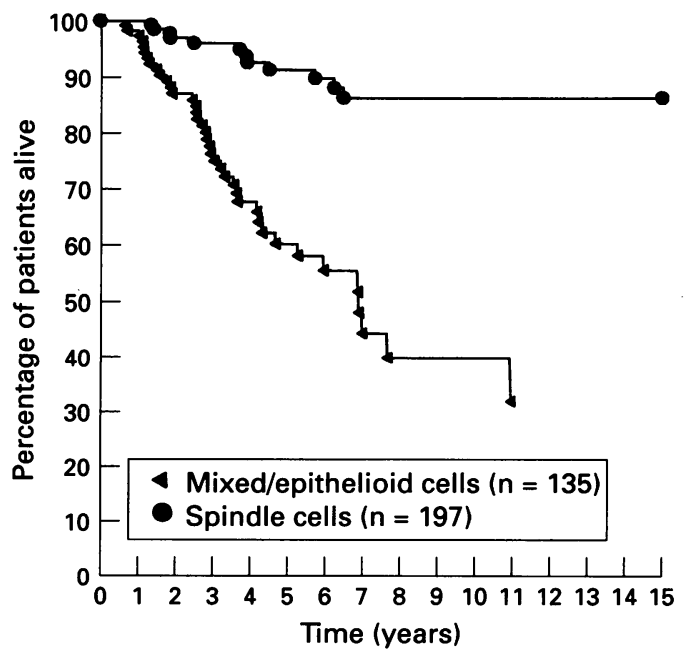

Figure 2 Kaplan-Meier curves showing the percentage of live patients according to tumour cell type. Patients with mixed or epithelioid cell tumours were more likely to die of metastatic disease than those with spindle cell tumours.

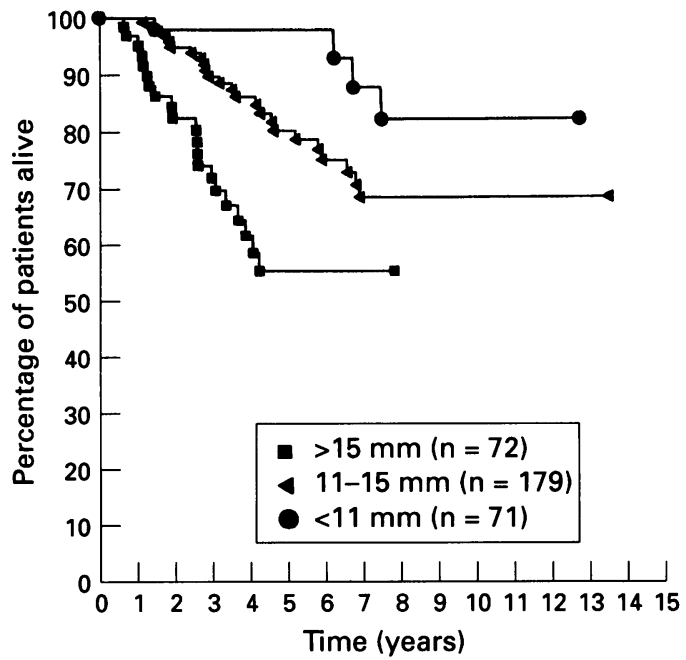

Figure 3 Kaplan-Meier curves showing the percentage of live patients according to largest tumour diameter. Patients with larger tumours showed poorer survival.

All two way interactions between variables in the above multivariate model were examined and this suggested that an interaction existed between sagittal location and tumour cell type, with mixed/epithelioid cell tumours being associated with a higher rate of metastatic death if located superiorly in the eye $(p=0.053)$. Although this interaction did not reach the conventional level of statistical significance $(p<0.05)$, it was included as an extra term in the final statistical model (Table 3) because it accounted for the strong significance of sagittal tumour location in the multivariate model compared with nonsignificance in the univariate setting. In the final multivariate model, the predictive factors were therefore (i) patient age greater than 60 years at diagnosis $(p<0 \cdot 001)$, (ii) largest tumour diameter of $16 \mathrm{~mm}$ or more $(\mathrm{p}=0.001)$, (iii) mixed/epithelioid cell type $(p=0.002)$, (iv) superior tumour of mixed/ epithelioid cell type (over and above (iii)) $(p=0.002)$, and $(v)$ lack of adjunctive plaque radiotherapy $(p=0.021)$ (Table 3 ).

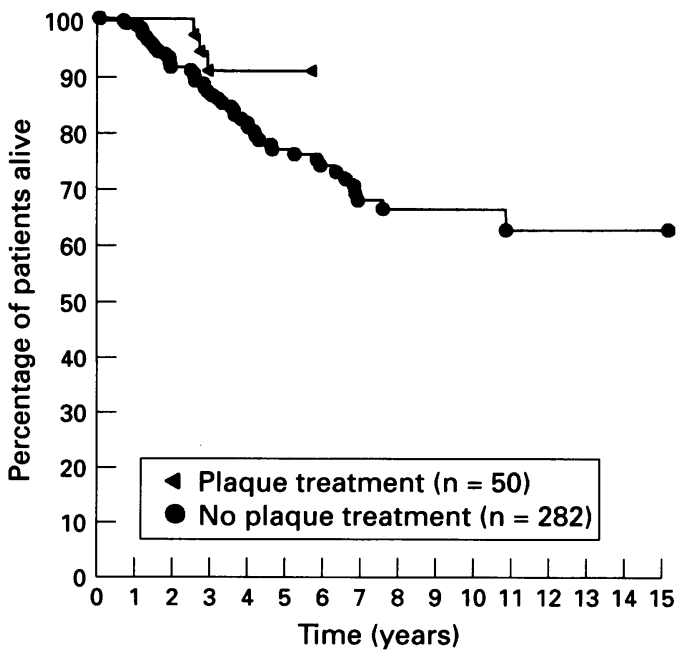

Figure 4 Kaplan-Meier curves showing the percentage of live patients according to adjunctive plaque radiotherapy. Patients receiving adjunctive plaque radiotherapy showed improved survival. 
Table 3 Metastatic death after local resection. Multivariate analysis after adjusting for interaction between cell type and sagittal tumour location

\begin{tabular}{|c|c|c|c|c|c|c|}
\hline \multirow[b]{2}{*}{ Variable } & \multirow[b]{2}{*}{ Categories } & \multirow[b]{2}{*}{$\begin{array}{l}\text { No of } \\
\text { patients }\end{array}$} & \multirow[b]{2}{*}{$\begin{array}{l}\text { Relative rate of } \\
\text { metastatic death }\end{array}$} & \multicolumn{2}{|c|}{$95 \%$ Confidence interval for $R R$} & \multirow[b]{2}{*}{ p Value } \\
\hline & & & & $\begin{array}{l}\text { Lower } \\
\text { limit }\end{array}$ & $\begin{array}{l}\text { Upper } \\
\text { limit }\end{array}$ & \\
\hline Age at diagnosis (years) & $\begin{array}{l}\leqslant 60 \\
>60\end{array}$ & $\begin{array}{r}235 \\
87\end{array}$ & $\begin{array}{l}1 \cdot 00 \\
2 \cdot 93\end{array}$ & $\overline{1.62}$ & $\overline{5} \cdot 32$ & $<0.001$ \\
\hline $\begin{array}{l}\text { Superior tumour with } \\
\text { epithelioid cells }\end{array}$ & $\begin{array}{l}\text { No } \\
\text { Yes }\end{array}$ & $\begin{array}{r}279 \\
43\end{array}$ & $\begin{array}{l}1.00 \\
3.07\end{array}$ & $\overline{1.53}$ & $6 \cdot 17$ & 0.002 \\
\hline $\begin{array}{l}\text { Tumour diameter (mm) } \\
\text { (pathology measurement) }\end{array}$ & $\begin{array}{l}<16 \\
\geqslant 16\end{array}$ & $\begin{array}{r}250 \\
72\end{array}$ & 1.00 & $\overline{1.59}$ & - & 0.001 \\
\hline Cell type & $\begin{array}{l}\text { Spindle } \\
\text { Mixed/epithelioid }\end{array}$ & $\begin{array}{l}192 \\
131\end{array}$ & $\begin{array}{l}2 \cdot 94 \\
1 \cdot 00 \\
3 \cdot 22\end{array}$ & $\frac{1.59}{1.53}$ & $\begin{array}{l}3.45 \\
\frac{6}{6} \cdot 77\end{array}$ & 0.002 \\
\hline Adjunctive brachytherapy & $\begin{array}{l}\text { No } \\
\text { Yes }\end{array}$ & $\begin{array}{r}274 \\
48\end{array}$ & $\begin{array}{l}1.00 \\
0.24\end{array}$ & $\overline{0.07}$ & $\overline{0} 81$ & 0.021 \\
\hline
\end{tabular}

^Total number of patients is adjusted to 322 because pathological diameter is not recorded for 10 patients.

The predictive factors were each given a score of +1 and patients were allocated into risk groups according to the sum of these risk factors. Figure 5 shows the Kaplan-Meier survival curves which give the time to metastatic death according to the risk group. Approximately $92 \%$ of 142 patients survived 15 years if less than two risk factors were present. At the other end of the scale, only $27 \%$ of 31 patients survived 3.5 years if more than three risk factors were present. Six years postoperatively, $76 \%$ of patients were alive if two risk factors were present compared with $57 \%$ of patients with three risk factors.

POSTOPERATIVE EVENTS

A forward stepwise regression procedure was performed to determine whether metastatic death was statistically related to (i) residual or recurrent tumour, (ii) subsequent enucleation for residual or recurrent tumour, and (iii) enucleation for retinal detachment or phthisis. This showed that the only subsequent event showing a statistically significant association with the relative rate of metastatic death was enucleation for persistent intraocular tumour $(\mathrm{p}=0.017)$ (Table 4).

The regression procedure was repeated after categorising the persistent intraocular tumour in the enucleated eye according to size and extraocular extension. This showed that metastatic death was associated with enucleation for large persistent tumour $(p=0.002)$ and

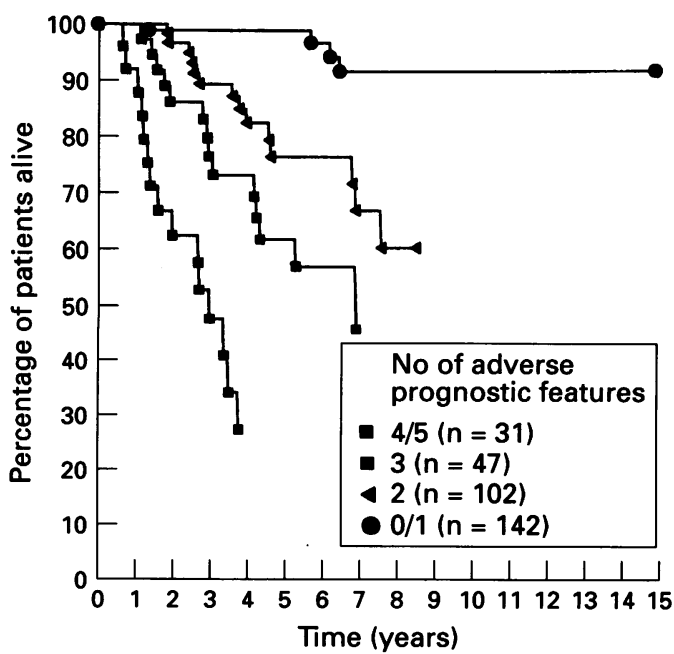

Figure 5 Kaplan-Meier curves showing the percentage of live patients according to the number of adverse prognostic features. with small persistent tumour with extraocular extension $(p=0.019)$ but not with small persistent tumour without extraocular extension $(p=0 \cdot 855)$ (Table 5).

\section{Discussion}

This is the largest study on survival after local resection performed to date, because it includes 332 patients, with maximum follow up of up to almost 21 years, few losses to follow up, and documentation of a large number of variables.

Many of the adverse prognostic factors after local resection have previously been shown to be important in patients treated by enucleation or radiotherapy. These include presence of epithelioid cells, large tumour size and old age at time of treatment. Similarly, the lack of significance of sex has previously been noted after other forms of treatment. ${ }^{35}$

There are a few notable differences between our results and those of other workers. Unlike other studies, ${ }^{9}$ our data do not show a statistically increased risk of metastatic disease in patients with anterior tumour extension, although there does seem to be a trend in this direction. This is perhaps because few of the tumours we resected were located entirely behind the equator of the eye. Our finding that mixed and epithelioid cell tumours are particularly associated with a poorer prognosis if located superiorly has not been reported previously. Whether other workers have not studied sagittal tumour location or whether they have found this variable to be insignificant is uncertain. This surprising statistical result may be due to chance or to previously unrecognised factors. In any case, the combined effect of sagittal tumour location and tumour cell type on survival merits further study.

An important finding is that the risk of metastatic death is higher in patients who undergo secondary enucleation for persistent tumour that is large or that extends extraocularly. The numbers of patients with these adverse features are small so that these results are only tentative and need to be confirmed by further studies; however, data published by other workers indicate that failure of local tumour control is associated with a significantly increased risk of metastatic death after plaque radiotherapy 36 and with a nonsignificant increase in mortality after proton beam radiotherapy. ${ }^{38}$ There are two possible 
Table 4 Metastatic death after local resection. Multivariate analysis including postoperative events

\begin{tabular}{|c|c|c|c|c|c|c|}
\hline \multirow[b]{2}{*}{ Variable } & \multirow[b]{2}{*}{ Categories } & \multirow[b]{2}{*}{$\begin{array}{l}\text { No of } \\
\text { patients }\end{array}$} & \multirow[b]{2}{*}{$\begin{array}{l}\text { Relative rate of } \\
\text { metastatic death }\end{array}$} & \multicolumn{2}{|c|}{$95 \%$ Confidence interval for $R R$} & \multirow[b]{2}{*}{ p Value } \\
\hline & & & & $\begin{array}{l}\text { Lower } \\
\text { limit }\end{array}$ & $\begin{array}{l}\text { Upper } \\
\text { limit }\end{array}$ & \\
\hline Age at diagnosis (years) & $\begin{array}{l}\leqslant 60 \\
>60\end{array}$ & $\begin{array}{r}235 \\
87\end{array}$ & $\begin{array}{l}1.00 \\
2 \cdot 68\end{array}$ & $\overline{1} \cdot 45$ & $\overline{4} \cdot 96$ & 0.002 \\
\hline Superior tumour with & No & 279 & $1 \cdot 00$ & - & -10 & 0.001 \\
\hline Tumour diameter (mm) & $\begin{array}{l}<16 \\
<16\end{array}$ & $\begin{array}{r}43 \\
250 \\
72\end{array}$ & $\begin{array}{l}3.13 \\
1.00\end{array}$ & $\frac{1}{1} \cdot 57$ & $\begin{array}{l}6 \cdot 25 \\
-\end{array}$ & 0.002 \\
\hline Cell type & $\begin{array}{l}\text { Spindle } \\
\text { Mixed/epithelioid }\end{array}$ & $\begin{array}{r}72 \\
191 \\
131\end{array}$ & $\begin{array}{l}2 \cdot 03 \\
1.00 \\
3 \cdot 13\end{array}$ & $\begin{array}{l}1 \cdot 42 \\
\overline{1} \cdot 48\end{array}$ & $\begin{array}{l}4.95 \\
- \\
6 \cdot 55\end{array}$ & 0.003 \\
\hline Adjunctive brachytherapy & $\begin{array}{l}\text { No } \\
\text { Yes }\end{array}$ & $\begin{array}{r}274 \\
48\end{array}$ & $\begin{array}{l}1.00 \\
0.27\end{array}$ & 0.08 & $\overline{0} \cdot 95$ & $0 \cdot 040$ \\
\hline $\begin{array}{l}\text { Subsequent enucleation for } \\
\text { persistent tumour }\end{array}$ & $\begin{array}{l}\text { No } \\
\text { Yes }\end{array}$ & $\begin{array}{r}299 \\
33\end{array}$ & $\begin{array}{l}1 \\
2 \cdot 25\end{array}$ & $\overline{1} \cdot 15$ & $4 \cdot 39$ & $0 \cdot 017$ \\
\hline
\end{tabular}

«Total number of patients is adjusted to 322 because pathological diameter is not recorded for 10 patients.

explanations for such results. It is possible that in a proportion of cases metastatic death after local resection (and indeed after radiotherapy) is caused by malignant cells which disseminate from viable tumour persisting in the eye after inadequate treatment. An alternative explanation is that large size and extraocular extension of recurrent tumours are indicators of aggressive tumour behaviour, with tumour dissemination occurring before treatment and with microscopic tumour deposits in the liver behaving in the same aggressive manner as microscopic deposits in the eye. In other words, the question is whether persistent viable tumour after unsuccessful conservative treatment causes metastatic death or whether persistent tumour and metastatic death are both indicators of adverse prognostic factors that were not included in predictive statistical models.

In this study, (i) histologically incomplete tumour resection, and (ii) small persistent tumours treated by enucleation were not associated with an increased risk of metastatic disease. This is possibly because prompt and successful secondary treatment prevented growth and dedifferentiation of residual tumour cells in the eye, or because many of the persistent tumours had a low metastatic potential, or both of these reasons. Treatment of known residual or recurrent disease may also have inadvertently prevented metastatic spread. from unrecognised microscopic tumour deposits, as implied by the efficacy of adjunctive plaque radiotherapy (see below). Some patients with apparently complete excision on histology and ophthalmoscopy developed local tumour recurrence and this suggests that microscopic tumour seedlings and extensions were sometimes missed both by the pathologist and the surgeon.

Adjunctive plaque radiotherapy was introduced in 1986 as a routine procedure to reduce the incidence of local tumour recurrence, and indeed in a parallel study, we show that adjunctive plaque radiotherapy is effective at preventing local tumour recurrence after trans-scleral local resection (Cox multivariate analysis, $p=0.018) .{ }^{34}$ In 1989 , we adopted more aggressive resection with wider clearance margins, and adjunctive laser photocoagulation to reduce the incidence of radiational complications. The finding that adjunctive plaque radiotherapy is associated with a better prognosis for survival is serendipitous. Our results suggest that in eradicating microscopic tumour deposits left in the eye after local resection, adjunctive plaque radiotherapy prevents not only local tumour recurrence but also metastasis. The effect of adjunctive plaque radiotherapy on metastasis was not studied in a randomised and prospective fashion so that further investigation is necessary. Nevertheless, it is noteworthy that patients treated with adjunctive plaque radiotherapy tended to have larger tumours and would therefore have been expected to have a higher incidence of metastatic disease not lower.

Table 5 Metastatic death after local resection. Multivariate analysis adjusting for size of persistent tumour in enucleated eyes and extraocular extension

\begin{tabular}{|c|c|c|c|c|c|c|}
\hline \multirow[b]{2}{*}{ Variable } & \multirow[b]{2}{*}{ Categories } & \multirow[b]{2}{*}{$\begin{array}{l}\text { No of } \\
\text { patients }\end{array}$} & \multirow{2}{*}{$\begin{array}{l}\text { Relative } \\
\text { rate of } \\
\text { metastatic } \\
\text { death }\end{array}$} & \multicolumn{2}{|c|}{$95 \%$ Confidence interval for $R R$} & \multirow[b]{2}{*}{$p$ Value } \\
\hline & & & & $\begin{array}{l}\text { Lower } \\
\text { limit }\end{array}$ & $\begin{array}{l}\text { Upper } \\
\text { limit }\end{array}$ & \\
\hline Age at diagnosis (years) & $\begin{array}{l}<60 \\
\geqslant 60\end{array}$ & $\begin{array}{r}235 \\
87\end{array}$ & $\begin{array}{l}1 \cdot 00 \\
2 \cdot 92\end{array}$ & $\overline{1} \cdot 57$ & $\overline{5} \cdot 45$ & 0.001 \\
\hline \multirow{5}{*}{$\begin{array}{l}\text { Superior tumour with } \\
\text { epithelioid cells } \\
\text { Tumour diameter (mm) } \\
\text { (pathology measurement) } \\
\text { Cell type }\end{array}$} & No & 279 & $1 \cdot 00$ & - & - & 0.001 \\
\hline & Yes & 43 & 3.50 & $1 \cdot 72$ & $7 \cdot 13$ & \\
\hline & $\begin{array}{l}<16 \\
\geqslant 16\end{array}$ & $\begin{array}{r}250 \\
72\end{array}$ & $\begin{array}{l}1 \cdot 00 \\
3 \cdot 59\end{array}$ & $\overline{1} \cdot 83$ & $\overline{7} \cdot 01$ & $<0.001$ \\
\hline & Spindle & 191 & $1 \cdot 00$ & - & - & 0.003 \\
\hline & Mixed/epithelioid & 131 & 3.03 & 1.45 & $6 \cdot 34$ & \\
\hline \multirow{5}{*}{$\begin{array}{l}\text { Adjunctive brachytherapy } \\
\text { Enucleation for persistent } \\
\text { tumour }\end{array}$} & No & 274 & $1 \cdot 00$ & - & & 0.031 \\
\hline & $\begin{array}{l}\text { Yes } \\
\text { No }\end{array}$ & $\begin{array}{r}48 \\
299\end{array}$ & $\begin{array}{l}0 \cdot 25 \\
1\end{array}$ & $\begin{array}{l}0 \cdot 07 \\
-\end{array}$ & $0 \cdot 88$ & \\
\hline & $\begin{array}{l}\text { Yes, for large tumour } \\
\text { Yes, for small tumour with }\end{array}$ & 9 & $5 \cdot 98$ & 1.95 & $18 \cdot 34$ & 0.002 \\
\hline & $\begin{array}{l}\text { extraocular extension } \\
\text { Yes, for small tumour without }\end{array}$ & 9 & $3 \cdot 65$ & $1 \cdot 24$ & $10 \cdot 74$ & 0.019 \\
\hline & extraocular extension & 15 & $1 \cdot 10$ & 0.40 & $3 \cdot 00$ & 0.855 \\
\hline
\end{tabular}

^Total number of patients is adjusted to 322 because pathological diameter is not recorded for 10 patients. 
Lack of adjunctive plaque radiotherapy seemed to be associated with an increased mortality even in patients without residual or recurrent disease $(28 / 20614 \%$ versus $2 / 44$ $5 \%$ ). This crude estimate is in keeping with the results of our multivariate analyses, which show adjunctive plaque radiotherapy to be an independent prognostic indicator even when enucleation for persistent tumour is included in the model $(p=0.031)$ (Table 5). These results would seem to suggest that adjunctive plaque radiotherapy may prevent metastatic disease in some cases because it prevents seeding from microscopic deposits. We, therefore, share the concerns expressed by Robertson and associates about residual tumour after local resection, although we find that deposits in uveal tissue are more troublesome than deposits in sclera or retina. ${ }^{39}$ On the basis of these findings, we now excise tumours with wider clearance margins than before and routinely perform adjunctive treatment, which consists either of (i) ruthenium plaque radiotherapy or, if this is not technically possible, (ii) laser photocoagulation and cryotherapy to the margins and bed of the coloboma.

The 5 year mortality rates for patients with largest basal tumour diameters of $<11 \mathrm{~mm}$, $11-15 \mathrm{~mm}$, and $>15 \mathrm{~mm}$ were approximately $3 \%, 20 \%$, and $44 \%$ (Fig 3). These results seem better than those reported in a meta-analysis: by Diener-West and associates, which shows the 5 year mortality rates after treatment of uveal melanoma to be $16 \%$ for small tumours (large tumour diameter $<10-11 \mathrm{~mm}$ and tumour thickness $<2 \mathrm{~mm}-3 \mathrm{~mm}$ ), $32 \%$ for medium tumours (large tumour diameter $<15$ $\mathrm{mm}-16 \mathrm{~mm}$ and tumour thickness $3-8 \mathrm{~mm}$ ), and $53 \%$ for large tumours (large tumour diameter $>15 \mathrm{~mm}-16 \mathrm{~mm}$ or tumour thickness $\geqslant 8 \mathrm{~mm}) .^{3}$ If we had classified our tumours according to both height and diameter, then 103 of our tumours would have been placed in a less favourable category so that our survival figures would have been even better than those of Diener-West and associates. The most likely explanation for better survival after local resection is selection bias related to the need for good general health for hypotensive anaesthesia. In view of the hazards of comparing apparently similar data from different publications we would prefer to assess only our own data. We have previously shown that survival in 220 patients treated by local resection was not significantly different from that in a matched series of 239 patients treated by enucleation. ${ }^{40}$ On the basis of our findings, we continue to regard trans-scleral local resection as a reasonable alternative to enucleation, especially if some form of adjunctive local treatment is administered, and this applies to all tumours irrespective of size and location.

Overall 5 year survival figures have been reported as approximately $75-85 \%$ after helium ion radiotherapy, ${ }^{21}$ proton beam radiotherapy, ${ }^{20}$ cobalt plaque radiotherapy, ${ }^{41}$ and ruthenium plaque radiotherapy. ${ }^{42}$ These results do not seem markedly different from our own data, although as mentioned above there are severe limitations inherent in comparing results from different studies. Because we reserve local resection for patients we consider to be unsuitable for radiotherapy, there would not seem to be much scope for performing comparisons between these two treatments in a randomised prospective fashion.

The results of the present study with regard to the influence of adjunctive plaque radiotherapy on survival are only tentative as they were not obtained in a randomised prospective fashion. If survival is indeed improved by adjunctive treatment, this would imply that (i) residual tumour can cause metastatic disease, (ii) fatal tumour dissemination can occur after the patient presents, even if the tumour is of medium size or large, and that (iii) all patients without evidence of metastasis should receive urgent and total tumour destruction.

In the present study, differences in survival rates according to adjunctive radiotherapy seem to appear as early as the fourth year after treatment (Fig 4). This tentative result is not in keeping with the views expressed by others that (i) metastatic death within the first 7 years postoperatively is always due to tumour dissemination before treatment and that (ii) a minimum follow up interval of 7 years is essential to allow any comparisons between different forms of treatment. ${ }^{43}$ In this respect, it is noteworthy that (i) factors predicting metastatic death within the first 2 years may be different from those that predict more delayed onset of metastatic disease and death, ${ }^{16}$ and that (ii) the prognostic values of pretreatment variables may decline with time. ${ }^{44}$

In conclusion, this study confirms the findings of other workers that epithelioid cell type, largest basal tumour diameter, and old age are useful predictors of metastatic death and, in addition, identifies other adverse prognostic factors, such as lack of adjunctive plaque radiotherapy, delayed or inadequate treatment of residual or recurrent tumour, and superior tumour location within the eye of mixed and epithelioid tumours. These tentative results appear to contradict some general beliefs about the natural history of uveal melanomas and imply that these tumours should be treated aggressively and urgently. The prognostic score developed in this study allows survival after local resection to be described in a more meaningful manner than has hitherto been possible and in future may facilitate the selection of patients for adjunctive systemic immunotherapy or chemotherapy.

Supported in part by grants from the Scottish Home and Health Department, 150/799, Greater Glasgow Health Board, the Ross Foundation for the Prevention of Blindness (Scotland), and the Hayward Foundation.

The authors wish to thank all the ophthalmologists who have The authors wish to thank all the ophthalmologists who have
referred patients to the Ophthalmic Oncology Service and who referred patients to the Ophthalmic Oncology Service and who
have returned questionnaires. We also acknowledge the contrihave returned questionnaires. We also acknowledge the contri-
bution of Professor W R Lee, who performed the pathological bution of Professor W R Lee, who perf
examination of the resected tumours.

1 Jensen OA. Malignant melanomas of the uvea: a recent follow-up of cases in Denmark, 1943-1952. Acta Ophthalmol (Copenh) 1970; 48: 1113-28.

2 Char DH. Metastatic choroidal melanoma. $A m$ f Ophthalmol 1978; 86: 76-80.

3 Diener West M, Hawkins BS, Markowitz JA, Schachat AP. A review of mortality from choroidal melanoma. II. A meta-analysis of 5-year mortality rates following enucleation, 1966 through 1988. Arch Ophthalmol 1992; 110: 245-50. 
4 Seddon JM, Polivogianis L, Hsieh CC, Albert DM, Gamel JW, Gragoudas ES. Death from uveal melanoma. Number of epithelioid cells and inverse SD of nucleolar
area as prognostic factors. Arch Ophthalmol 1987; 105: area as

5 Gamel JW, McCurdy JB, McLean IW. A comparison of prognostic covariates for uveal melanoma Invest Ophthalmol Vis Sci 1992; 33: 1919-22.

6 Meecham WJ, Char DH. DNA content abnormalities and prognosis in uveal melanoma. Arch Ophthalmol 1986; 104 1626-9.

7 de la Cruz PO Jr, Specht CS, McLean IW. Lymphocytic infiltration in uveal malignant melanoma. Cancer 1990 65: $112-5$.

8 Shammas HF, Blodi FC. Prognostic factors in choroidal and ciliary body melanomas. Arch Ophthalmol 1977; 95: 63-9.

9 Seddon JM, Albert DM, Lavin PT, Robinson N. A prognostic factor study of disease-free interval and survival following enucleation for uveal melanoma. Arch Ophthalmol 1983; 101: 1894-9.

10 Packard RB. Pattern of mortality in choroidal malignant melanoma. Brf Ophthalmol 1980; 64: 565-75.

11 Folberg R, Rummelt V, Parys-Van Ginderdeuren R, Hwan $\mathrm{T}$, Woolson RF, Pe'er J, et al. The prognostic value of tumor blood vessel morphology in primary uvea melanoma. Ophthalmology 1993; 100: 1389-98.

12 Coleman DJ, Silverman RH, Rondeau MJ, Lizzi FL, McLean IW, Jakobiec FA. Correlations of acoustic tissue typing of malignant melanoma and histopathologic typing of malignant melanoma and histopathologic features as a
110: $380-8$.

13 Affeldt JC, Minckler DS, Azen SP, Yeh L. Prognosis in uveal melanoma with extrascleral extension. Arch Ophthalmol 1980; 98: 1975-9.

14 Gragoudas ES, Seddon JM, Egan KM, Glynn RJ, Goitein $\mathrm{M}$, Munzenrider J, et al. Metastasis from uveal melanoma after proton beam irradiation. Ophthalmology 1988; 95: 992-9.

15 Augsburger J, Gamel JW, Shields JA, Markoe AM, Brady LW. Post-irradiation regression of choroidal melanomas as a risk factor for death from metastatic disease. Ophthalmology 1987; 94: 1173-7.

16 Glynn RJ, Seddon JM, Gragoudas ES, Egan KM, Hart LJ. Evaluation of tumor regression and other prognostic Evaluation of tumor regression and other prognostic
factors for early and late metastasis after proton irradiafactors for early and late metastasis after proton irradia-
tion of uveal melanoma. Ophthalmology 1989; 96: tion of

17 Lommatzsch PK. Results after beta-irradiation (106Ru/ $106 \mathrm{Rh}$ ) of choroidal melanomas: 20 years' experience. Brf Ophthalmol 1986; 70: 844-51.

18 Char DH, Quivey JM, Castro JR, Kroll S, Phillips T. Helium ions versus iodine 125 brachytherapy in the management of uveal melanoma. Ophthalmology 1993; 100: 1547-54.

19 Packer S, Stoller S, Lesser ML, Mandel FS, Finger PT. Long-term results of iodine 125 irradiation of uvea Long-term results of iodine 125 irradiatio
melanoma. Ophthalmology 1992; 99: 767-74.

20 Gragoudas ES, Seddon JM, Egan K, Glynn $R$ Munzenrider J, Austin Seymour M, et al. Long-term results of proton beam irradiated uveal melanomas. Ophthalmology 1987; 94: 349-53.

21 Char DH, Castro JR, Kroll SM, Irvine AR, Quivey JM Stone RD. Five-year follow-up of helium ion therapy for uveal melanoma. Arch Ophthalmol 1990; 108: 209-14.

22 Foulds WS. The local excision of choroidal melanomata. Trans Ophthalmol Soc UK 1973; 93: 343-6.

23 Peyman GA, Juarez CP, Diamond JG, Raichand M. Ten years' experience with eye wall resection for uveal maligyears' experience with eye wall resection for uveal

24 Shields JA, Shields CL, Shah P, Sivalingam V. Partial lamellar sclerouvectomy for ciliary body and choroidal tumors. Ophthalmology 1991; 98: 971-83.

25 Damato BE, Foulds WS. Surgical resection of choroidal melanomas. In: Ryan SJ, ed. Retina. 2nd ed. St Louis: CV Mosby, 1994.

26 Seddon JM, Gragoudas ES, Egan KM, Glynn RI, Howard S, Fante RG, et al. Relative survival rates after alternative
therapies for uveal melanoma. Ophthalmology 1990; 97: therapies

27 Foulds WS, Damato BE, Burton RL. Local resection versus enucleation in the management of choroidal melanoma. Eye 1987; 1: 676-9.

28 Char DH, Phillips TL, Andejeski Y, Crawford JB, Kroll S Failure of preenucleation radiation to decrease uveal melanoma mortality [see comments]. Am f Ophthalmol 1988; 106: 21-6.

29 Gragoudas ES, Char DH. Charged particle irradiation of uveal melanomas. In: Albert DM, Jakobiec FA, eds. Principles and practice of ophthalmology. Philadelphia: WB Saunders, 1994: 3233-44.

30 Damato BE, Paul J, Foulds WS. Predictive factors of visual outcome after local resection of choroidal melanoma. $\mathrm{Br} \mathcal{F}$ Ophthalmol 1993; 77: 616-23.

31 Todd JG, Colvin JR. Ophthalmic surgery. In: MacRae WR, Wildsmith JAW, eds. Induced hypotension. London: Elsevier (Biomedical Division), 1991: 257-69.

32 Cox DR, Oakes D. Analysis of survival data. London: Chapman and Hall, 1984.

33 Armitage P, Berry G. Statistical methods in medical research. 2nd ed. Oxford: Blackwell, 1987.

34 Damato BE, Paul J, Foulds WS. Risk factors for residual and recurrent uveal melanoma after trans-scleral local and recurrent uveal melanoma after trans

35 McLean IW, Foster WD, Zimmerman LE. Prognostic factors in small malignant melanomas of choroid and factors in small malignant melanomas of cho
ciliary body. Arch Ophthalmol 1977; 95: 48-58.

36 Abramson DH, Servodidio CA, McCormick B, Fass D Zang E. Changes in height of choroidal melanomas after plaque therapy. Br F Ophthalmol 1990; 74: 359-62.

37 Vrabec TR, Augsburger J, Gamel JW, Brady LW, Hernandez C, Woodleigh R. Impact of local tumo relapse on patient survival after cobalt 60 plaque radiotherapy. Ophthalmology 1991; 98: 984-8.

38 Gragoudas ES, Egan KM, Seddon JM, Walsh SM Munzenrider JE. Intraocular recurrence of uvea melanoma after proton beam irradiation. Ophthalmology melanoma after

39 Robertson DM, Campbell RJ, Weaver DT. Residua intrascleral and intraretinal melanoma: a concern with lamellar sclerouvectomy for uveal melanoma. $A m$ Ophthalmol 1991; 112: 590-3.

40 Foulds WS, Damato BE, Burton RL. Local resection in the management of choroidal melanoma. In: Bornfeld $\mathbf{N}$, Gragoudas ES, Höpping W, Lommatzsch PK, Wessing A, Zografos $\mathrm{L}$, eds. Proceedings of the international symposium
on tumours of the eye. Amsterdam: Kugler, 1991: 553-60.

41 Augsburger J, Gamel JW, Lauritzen K, Brady LW. Cobalt60 plaque radiotherapy vs enucleation for posterior uveal 60 plaque radiotherapy vs enucleation for posterior

42 Bornfeld N, Lommatzsch PK, Hirche H, Foerster $\mathrm{MH}$ Wessing A, Lommatzsch R, et al. Metastasis after brachytherapy of uveal melanomas with $\mathrm{Ru}-106 / \mathrm{Rh}-106$ plaques. In: Bornfeld N, Gragoudas ES, Höpping W, Lommatzsch PK, Wessing A, Zografos L,

43 Manschot WA, van Strik R. Uveal melanoma: therapeutic consequences of doubling times and irradiation results; a review. Int Ophthalmol 1992; 16: 91-9.

44 Gamel JW, McLean IW, Greenberg RA. Interval-byinterval Cox model analysis of 3680 cases of intraocular melanoma shows a decline in the prognostic value of size and cell type over time after tumor excision. Cancer 1988; 61: 574-9. 